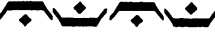

委員会報告

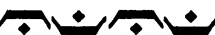

\section{製鉄所におけるロボットの実現性評価}

(C) 1983 ISIJ

\title{
Study on the Feasibility of Robotizing Work at Steelworks
}

\section{Tuneomi IsHIZAKI}

\section{1. 緒}

言

1980 年代は「産業口ボットの時代」と呼ばれるほどロ ボットの普及は目ざましいものがある，特にマイクロエ レクトロニクスに関する技術革新により知能ロボットも 実現し，ますますロボット化が身近なものになつてきて いる. 一方，今後の鉄鋼業には高㛔化・高賃金化あるい は悪環境・危険作業者不足といつた労働環境の変化に対 応しつつ, 生産性向上, コストダウン, 品質向上といつ た数々の問題を解決して行かねばならない状況にある.

このような背景から，圧延設備分科会の参加各社 14 社（鉄鋼メーカ 7 社, 機械メーカ 7 社）で構成される口 ボット研究小委員会が設置され，「製鉄所のロボット化」 をテーマに活動を行つてきた.

本小委員会では，口ボットに関するハード並びにソフ トの具体的な開発活動の展開を目的とはせずに，製鉄所

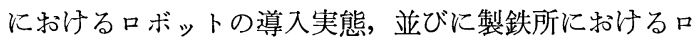
ボット化のニーズをアンケート方式によつて調查を行 い，今後のロボット化について取り組む示唆を与える段 階までのことを研究した。

この研究成果については第 27 回圧延設備分科会で

(1) 製鉄所におけるロボットの導入実態

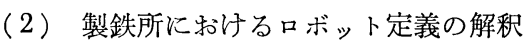

（3）製鉄所に打けるロボット化ニーズの実態

（4）ロボット化二ーズの実現難易度の評価

（5）ロボット化実現のための技術課題

（6）ロボットに関する技術動向

の内容を報告した。 ここではこのらち(1)（3)(4)(5) について要約をして報告する.

\section{2. 調查方 法}

調査は圧延設備分科会加入の鉄鋼 7 社 25 事業所から アンケート式によつて行つた。 アンケートは以下の考え 万に基づき実施した。

(1) 製鉄所に沶いてのロボットの導入実態と鉄鋼業 に持けるロボットのイメージを把握するために，現在製 鉄所で稼働している装置，機械などで「ロボット」と認
識しているもの，およびロボットらしきものを対象に抽 出する.

(以下，この調査を「ロボット字績」と略す)

（2）これから製鉄所のロボット化を考えていく場合 のニーズ状況を把握するために, 現在人手で行つてはい るがロボット化を期待する作業，あるいは機械を使つて いるがロボット化によつて効果が更に期待できる作業を 対象に抽出する.

(以下，この調査を「ロボット化ニーズ」と略す)

調査方法は所定のフォーマットに記入してもらら方法 で行い，その内容は，「作業名（または機器装㯰名）」, 「作業概要 (作業目的, 作業内容・手順, 作業上のポイン ト, ワークの使用条件, 略図) 」,「ロボット化の作業範 囲」,「ロボット化する目的」,「ロボット化の条件・機能 (環境条件, 対象物の形状, 重量, サイクルタイム, 作業 時の状態など）」，「技術的に解決すべき問題点」，「その 他」である. この第 1 次調査されたロボット化案件を更 に具現化するために, ロボット研究小委員会の委員によ る個別調查（第 2 次調査）を取り入れた.

\section{3. アンケートの集約結果}

アンケートの回収は, ロボット実績に関するもの 49 件, ロボット化ニーズに関するもの 110 件となつた. 以 下にとの概要を記す.

\section{1 工程別分析結果}

製鉄所の工程に基づき分類整理した結果は, 図 1 に示 すごとくである。

製鉄所におけるロボットの導入実績事例の多い工程 は, 高温・塵埃・有害ガスなどの環境条件の厳しい高炉， 転炉の工程, 並びに最終製品工程で人手による附帯作業 のウェイトが大きい冷延工程である.

また，ロボット化ニーズについてもロボット実績の傾 向と同様で，人手による附帯作業にロボット化の目が向 けられている.

\section{2 作業種類別分析結果}

作業の種類（目的）別に分類整理した結果は，図 2 に 示すごとくである. 


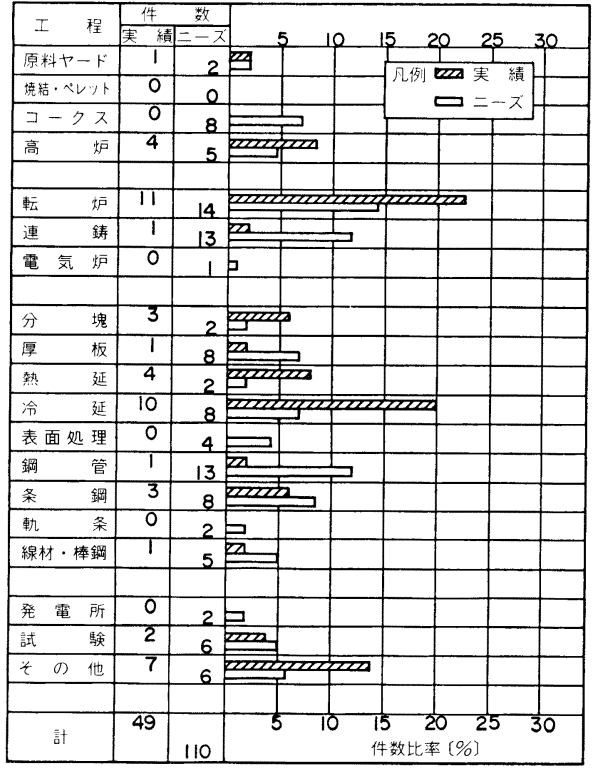

図 1 工 程 別 傾 向

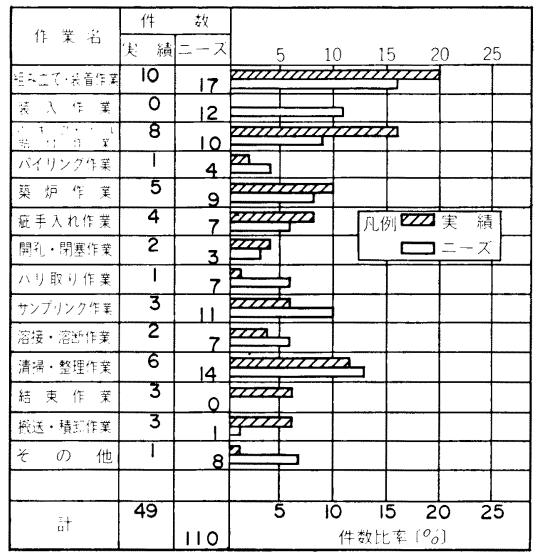

図 2 作業種類別傾向

作業内容からみると, 口ボット実績, ロボット化ニー ズともメインラインの作業工程よりも精整ラインなどの 下工程, あるいはオフラインで行われる作業にロボット 化の目が向けられている.

製鉄所においてロボットの導入実績の多い作業の種類 は，以下の作業があげられる。

（1）組み立て・装着作業（取り外し取り付け作業で 刃替, 蓋の着脱作業など)

(2) マーキング・ラベル貼付作業

（3）築炉作業（耐火物の取り壊し作業も含む）

（4）清掃・整理作業（屑処理，除涬作業など）

これらは, 製鉄所に打いて比較的単純絽り返し作業に属 するものへの導入であると言える.

ロボット化のニーズでは, ロボット実績と同じ傾向を

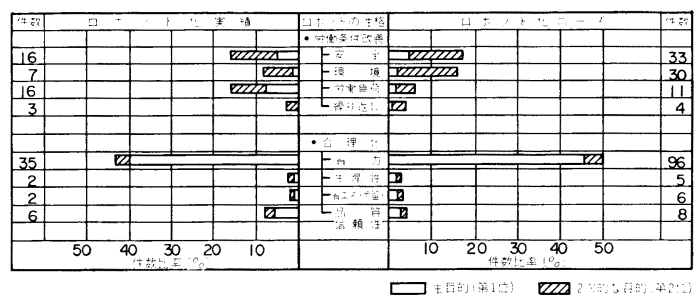

図 3 ロボット化の目的別傾向

示しているが，品質重視時代の背景もあつてサンプリン グ作業，涬などの不純物の除去や製品の末端処理などを 含んだ清掃・整理作業にも拡大されていく傾向が見られ る.

\section{3 ロボット化の目的別分析結果}

ロボット化の目的別に分類整理した結果は, 図 3 に示 すごとくである.

ロボット実績，ロボット化ニーズとも合理化，特に省 力化が最優先と考学られており, 労働条件の改善は 2 次 目的とする傾向が顕著である.

\section{4. 製鉄所におけるロボット導入に関する考察}

アンケートに回答されたロボット実績をJIS B 0134 で制定されているロボット分類にしたがい整理を試み た. その結果, アンケートで抽出された 49 件のらち 11 件は，マニプレータの機能を持たないもの，すなわち， 自動結束機, 無人台車, 自動疵見装置などは, 専用自動 機とみなし再整理を行つた. その結果製鉄所で導入され ているロボットの実態は, 図 4 , 表 1 のごとくである. すなわち

（1）現在製鉄所でロボットとして稼働しているロボ ットのタイプは, JIS で定められている主分類でいらマ ニアルマニプレータ, 次いで固定シーケンスロボットが ほとんどと言つてよい.このことから製鉄所においてロ ボットの高級化は，これからという段階であることがう かがえる.

（2）口ボット化が進んでいる作業は, 組み立て・装 置作業, マーキング・ラベル貼付作業, 除涬作業, 築炉 作業である. これらの作業のロボットについて共通して

\begin{tabular}{|c|c|c|}
\hline 口ホホット分類 & $\begin{array}{c}\text { <件 } \\
10 \\
\end{array}$ & \\
\hline マニアルマニプレータ & & \\
\hline 固定シーケンスロホホット & & \\
\hline 可変シーケンスロボット & $\square$ & \\
\hline ブレイバックロボット & $\square$ & \\
\hline 数値制衔ロホット & $\square$ & \\
\hline 知能口ボッ卜 & & \\
\hline 專 用 自 動 機 & 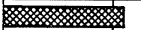 & \\
\hline
\end{tabular}

和双はボットとみなさないものの件数を示す

図4ロボット分類别アンケート件数分布 (ロボット実績) 
表 1 作業種類別ロボット分類分布 (ロボット実績)

\begin{tabular}{|c|c|c|c|c|c|c|c|}
\hline & $\begin{array}{l}P=P ル \\
P= \\
P レ-8\end{array}$ & 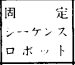 & 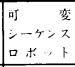 & $\mid \begin{array}{l}7 レ\{, 1 \\
0 x+1\end{array}$ & $\begin{array}{l}\text { 数值制御 } \\
\text { 口未，卜 }\end{array}$ & \begin{tabular}{|l|l} 
知 能 \\
口未丷,
\end{tabular} & $\begin{array}{l}\text { 䌊 作数 } \\
\text { (38 传 }\end{array}$ \\
\hline 粗元立て・装着作業 & ) & - & $\bullet$ & $\bullet$ & * & $\star$ & 10件: \\
\hline 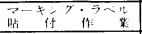 & $\star$ & 0 & $\bullet$ & $\star$ & $\bullet$ & 夫 & 7 \\
\hline 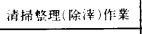 & ? & $\bullet$ & $\star$ & * & $\star$ & $\star$ & 5 \\
\hline 策灿(取り買し)作革 & 0 & $\bullet$ & $\star$ & $\star$ & $\star$ & $\star$ & 5 \\
\hline 批手人化作鄴 & - & * & * & * & * & ネ & 3 \\
\hline サンフリンク作業 & $\star$ & 0 & $\star$ & * & $\star$ & * & 3 \\
\hline 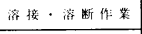 & $\bullet$ & * & $\star$ & $\bullet$ & $\star$ & * & 2 \\
\hline ヘイリンク佰掌 & * & $\bullet$ & $\star$ & * & $\star$ & $\star$ & 1 \\
\hline 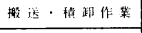 & $\star$ & $\bullet$ & * & * & * & $\star$ & 1 \\
\hline 銥 造 作 策 & $\star$ & $\bullet$ & $\star$ & * & * & * & 1 \\
\hline
\end{tabular}

$\star$ 太印該当なし

件数は円の直径で表示

いることは，人間自身がセンサの役割を受け持つている ロボットが大部分であること，第 2 にロボットの範囲を みると, 作業全体のごく一部分を受け持らロボットが主 役になつていないこと，第 3 に製鉄所において，比較的 単純な繰り返し作業に属するものへの適用であることで ある。

（3）ロボットの定義に関する解釈について考察して みると, マニアルマニプレータに属するものに, 製鉄所 内にはストリッパークレーンや油压ショベル, フォーク リフトなども該当することになるが，口ボット実績とし て抽出されていない。このことからこの種のような専用 機とみられるものは，ロボットと認識する考え方がない ように思われる.

\section{5. 製鉄所におけるロボット化ニーズに 関する考察}

回収されたロボット化ニーズについて，ロボットの設 置条件，周辺技術の適用条件など製鉄所間でも相違があ るので, 現状の平均的実態をべースにして, 作業イメー ジ化を簡略化し，かつできるだけ簡易な構造で考え，口 ボット化実現難易度の評価を行つた。

ロボット化ニーズの個々の案件について, 表 2 に示す 5 段階の評価基準で実現難易度の評価を行い，図 5 にそ の結果を示す. 技術的な問題を抱えている案件は, 約 60 \%を占めている. 一方，技術的にも，経済的にも問題な い案件はわずか $5 \%$ であり，製鉄所のロボット化には， まだまだ研究開発の必要性がらかがえる.

\section{$5 \cdot 1$ 製鉄所におけるロボットのイメージ}

前述したロボットに対するイメージに基づき，ロボッ トの諸元を設定し，それを統計的処理をし傾向分析を試 みた.この結果によると, 製鉄所におけるロボットの構 造面に打いては, 特異な条件を要求するケースは少なか つたが，高級ロボットに不可欠なソフト面では既存技術 以上のものを要求する傾向にある.

$5 \cdot 1 \cdot 1$ ワークの諸元
表 2 実現難易度評価基準

\begin{tabular}{|c|c|c|c|}
\hline 具現蜼易度 & in's & 補红说明 $(\forall, 之 / j)$ & 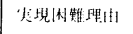 \\
\hline 丁. 業化管门 & (2) & 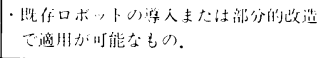 & $\cdots$ \\
\hline 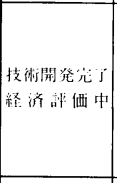 & 0 & 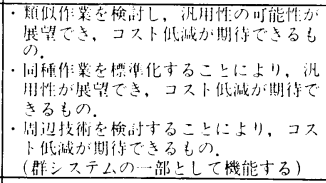 & $\ldots$ \\
\hline 技術娭封中 & $\Delta$ & 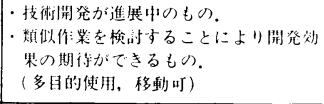 & \multirow{3}{*}{ 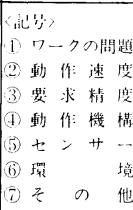 } \\
\hline 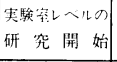 & $\Delta$ & 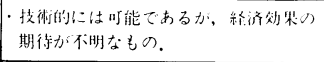 & \\
\hline 研 究 要 & $x$ & - 現状では，抆術的に洞敞なもの。 & \\
\hline
\end{tabular}

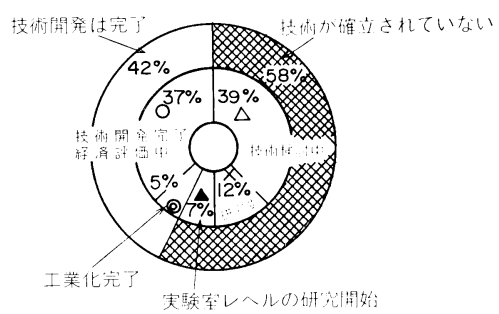

図 5 実現難易度分有

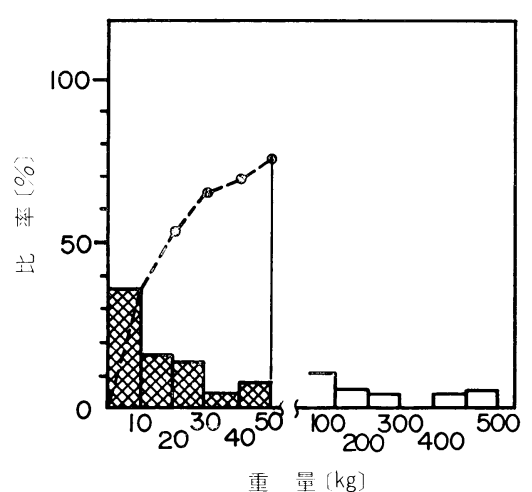

図 6 ワークの重量分布

ロボットの可搬重量は，ラベルなどの $\mathrm{g}$ 単位の非常に 軽いものから $2000 \mathrm{~kg}$ といらケースもあるが，図 6 に 示すごとく $50 \mathrm{~kg}$ 以下のものを対象とするケースが大 部分を占めている．重量物を対象とする作業は，組み立 て・装着作業での部品交換作業あるいはサンプリング用 端材処理などで非常に限られている。 また，ロボットが 把持するワークの断面形状は，川形，知形，L形など種 々ある. その大きさの分布は図 7 に示すとおりである.

$5 \cdot 1 \cdot 2$ 口ボット本体の諸元

ロボット本体の移動について，口ボットが配置される 周辺状況によつて必要自由度は変化するが，ここでは横 行, 前後進, 昇降のストロークについて分析した. その 

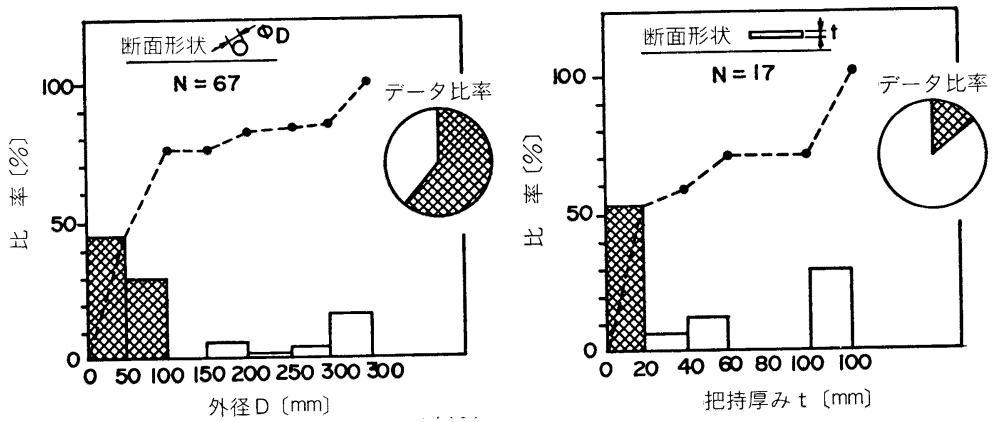

図7 ワークの断面寸法分布
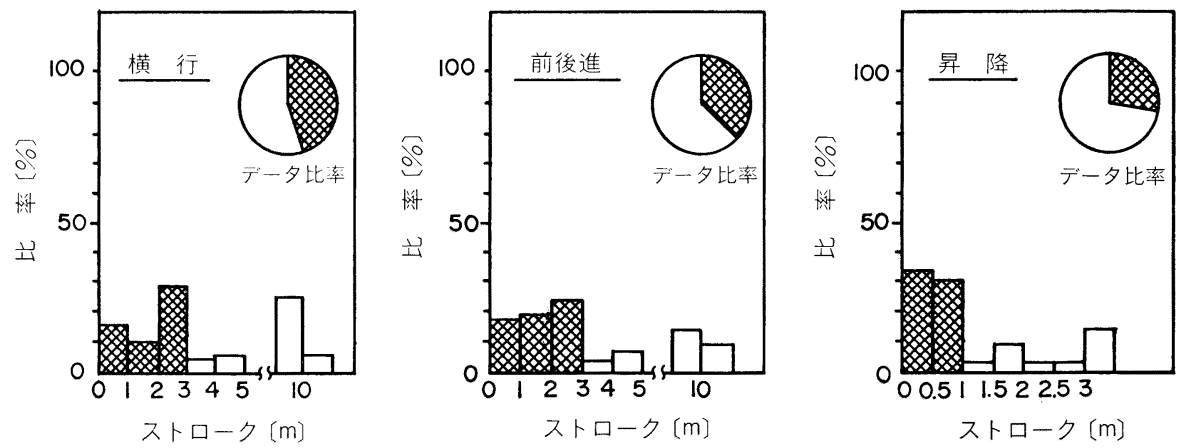

図 8 ロボット本体のストローク分布

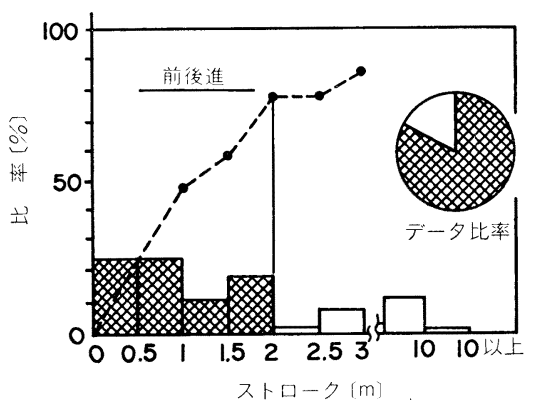

図 9 ロボットアームストローク分布

ストロークの分布状況は図 8 に示すごとくで, $\mathrm{X}$ 軸, $\mathrm{Y}$ 軸の両方向とも $3000 \mathrm{~mm}$ 以下, $\mathrm{Z}$ 軸方向は $1000 \mathrm{~mm}$ 以下が代表的仕様と想定できる.

$5 \cdot 1 \cdot 3$ ロボットアームの諸元

アームはロボットの必要機能で旋回, 前後進が代表的 機構であるとして諸元を検討した. このうち前後進スト ロークは, 図 9 に示すごとく $2000 \mathrm{~mm}$ あれば大部分の 作業が網羅できると想定される.

$5 \cdot 1.4$ 口ボット手首の諸元

ロボットの手の設計上自由度は重要な検討 課 題であ り, 作業種類ごとに分析した結果は, 表 3 に示すごとく でる. 装入作業, 清掃・整理作業（特に, 除涬作業）の 場合手首の自由度は不要であり, 組み立て・装着作業,
表 3 作業種類別手首の自由度分布

\begin{tabular}{|c|c|c|c|c|}
\hline \multirow{2}{*}{ 作業種類 } & \multicolumn{4}{|c|}{ 手首の自由長 } \\
\hline & 0 & 1 & 2 & 3 \\
\hline 1 組み立て・装着作業 & 0 & Q & $\circ$ & 0 \\
\hline $\begin{array}{|llll|}2 \text { 装 } & \text { 入 } & \text { 作 } & \text { 業 } \\
\end{array}$ & 0 & $\circ$ & - & $\circ$ \\
\hline 3ママーキンク・ラ゙゚睤付作菜 & $\star$ & 0 & $\bullet$ & 0 \\
\hline 4 パイリング作 業 & 0 & $\circ$ & $\star$ & $\star$ \\
\hline \begin{tabular}{|llll}
5 筑 & 炉 作 & 業
\end{tabular} & 0 & $\circ$ & 0 & 0 \\
\hline 6 疵手入れ作 業 & 0 & - & - & $\circ$ \\
\hline 7 開 孔 - 閉塞作 業 & $\circ$ & - & $\star$ & $\star$ \\
\hline 8 バリ取り作業 & $\circ$ & $\cdot$ & - & 0 \\
\hline 9 サンプリング作業 & $\circ$ & 0 & $\circ$ & 0 \\
\hline 10 溶接溶断作業 & $\circ$ & $\star$ & 0 & 0 \\
\hline 11 清掃 - 整理作業 & $\mathrm{O}$ & 0 & $\circ$ & $\circ$ \\
\hline 12 搬 送積 卸 作 業 & $\star$ & $\bullet$ & $\star$ & $\bullet$ \\
\hline \begin{tabular}{|lll}
13 & द & の
\end{tabular} & ० & $\star$ & (๑) & 0 \\
\hline
\end{tabular}

マーキング・ラベル貼付作業, サンプリング作業など位 置決め制御が伴う作業においては, 多自由度が要求され ることがらかがえる.

\section{$5 \cdot 1.5$ 位置決め精度の諸元}

精度に関する分析結果は, 図 10 に示すごとくであ る. $\pm 1 \mathrm{~mm}$ 以下の精度を要求するケースは比較的少な いが，溶接溶断作業，バリ取り作業などは $\pm 1 \mathrm{~mm}$ 以下 


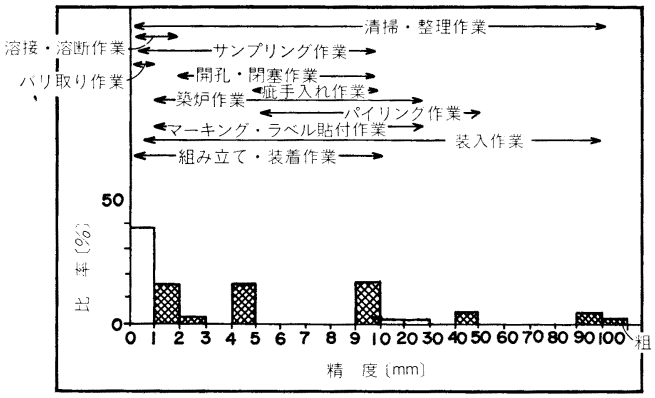

図 10 位置決め精度分布
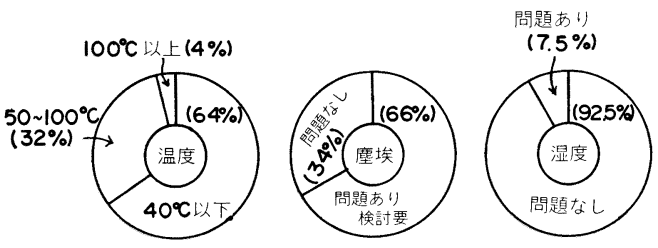

図 11 環境条件の傾向

が要求される.

\section{$5 \cdot 1 \cdot 6$ 環境}

ロボット本体の環境条件は, 図 11 亿示すごとくであ る. 塵埃は問題となるヶースがかなりあるが，温度，湿 度についてはほとんど問題とならない状況である。

\section{$5 \cdot 2$ ロボット化実現のための技術的課題}

製鉄所に括けるロボット化ニーズに関する実現難易度 の分布状況と, 主たる技術課題の内容は表 4 亿示すごと くである. 総括的に言えることは，センシングに関する 問題がクローズアップされて抒り，口ボット化を進める 上で重要なファクタになることが，図 12 に示さ机る口 ボット実績との対比から推測される. 特に, 位置や力に 関するセンシングについての研究開発が望まれる. 以下 に製鉄所に関わる作業の種類別の技術課題について述べ る.

\section{（1）組久立て・装着作業}

部品の取り外し取り付けなどの交換作業や蓋あるいは 工具の着脱作業など物を所定の位置にセットしていく作 業で，技術課題も比較的少なくロボット化のニーズも高 い作業内容である.

この種の作業に抢いては, 形状の異なつた物を把持す るためのグリップ感覚や対象物の微妙な位置ずれ認識の ため, 高感度の触覚センサの開発が技術課題としてあげ られる.

（2）装入作業

この種の作業は, ある容器に物を入れる作業, たとえ ば鉄板装入，パウダの均一散布の作業など，あるいは物 と物との間にマンボを挿入する作業で，比較的位置決め は粗くてよいヶースが多い。したがつて，現状の技術の
表 4 作業種類別実現難易度状況と技術課題

\begin{tabular}{|c|c|c|c|c|c|c|c|c|c|}
\hline \multirow[b]{2}{*}{ 作:棠种類 } & \multicolumn{5}{|c|}{ 热垷難易度 } & \multicolumn{4}{|c|}{ 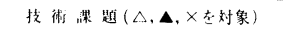 } \\
\hline & (3) & 0 & $\triangle$ & $\Delta$ & $\times$ & Bis & $\begin{array}{c}\text { E } \\
\text { biffery }\end{array}$ & \begin{tabular}{|l|l}
$s$ \\
$s y s t e m$
\end{tabular} & 门たる課題 \\
\hline 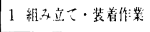 & $\bullet$ & 0 & $\circ$ & $\star$ & $\circ$ & $\circ$ & $\circ$ & $\circ$ & 触觉センサーの开開発 \\
\hline 2 装 入 作: 掌 & $\circ$ & 0 & $\circ$ & $\circ$ & $\star$ & 0 & o & $\circ$ & \\
\hline 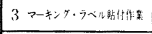 & $\circ$ & $\circ$ & O & $\star$ & $\star$ & $\circ$ & 0 & 0 & 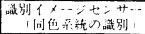 \\
\hline 4 パイリング作業 & $\star$ & $\circ$ & $\circ$ & $\star$ & $\star$ & $\star$ & $\circ$ & $\star$ & 動伤速度の高速化 \\
\hline 5 築 炊 作 業 & $\star$ & $\circ$ & 0 & $\star$ & 0 & $\mathrm{O}$ & 0 & $\circ$ & 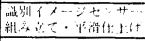 \\
\hline 6 㾁手人机作: 業 & $\star$ & $\star$ & O & $\circ$ & $\circ$ & $\mathrm{O}$ & $\star$ & $\circ$ & 㧗の程度の蚞出 \\
\hline 7 開孔 - 閉寨作業 & $\star$ & - & $\circ$ & $\star$ & $\star$ & $\circ$ & $\circ$ & $\star$ & \\
\hline 8バリ取り作業 & $\circ$ & $\circ$ & 0 & $\circ$ & $\star$ & 0 & $\star$ & $\star$ & 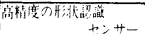 \\
\hline 9 サンプリング作業 & $\star$ & 0 & 0 & $\circ$ & $\circ$ & 0 & 0 & $\circ$ & 洏丁作算 \\
\hline 10 溶接 - 浮断作業 & $\circ$ & 0 & $\circ$ & $\star$ & $\star$ & $\circ$ & $\star$ & $\star$ & 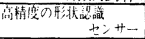 \\
\hline 11 清摔・整理倠:業 & $\star$ & 0 & 0 & $\star$ & $\circ$ & 0 & 0 & $\circ$ & 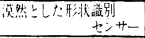 \\
\hline 12 搬送筧卸作業 & $\star$ & $\star$ & $\star$ & $\star$ & $\circ$ & $\star$ & $\star$ & $\circ$ & \\
\hline 13 そ $\quad$ 他 & $\star$ & * & 0 & $\circ$ & 0 & 0 & 0 & $\circ$ & \\
\hline 㐖 少 说 明 & $\triangle$ & 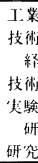 & $\begin{array}{l}\text { 成 } \\
\text { 楀 } \\
\end{array}$ & 中 & & & 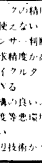 & & \\
\hline
\end{tabular}

表中の円の直径は件数を表す

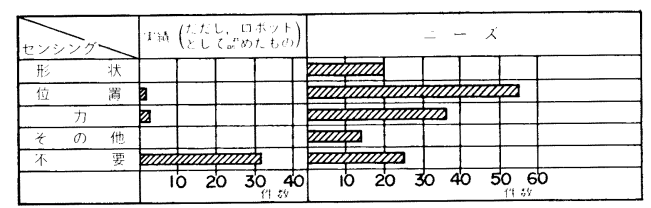

図12ロボット实績とニーズのセンシング傾向

組久合わせで対応できる作業と考兄られるが，周辺技術 の研究, 作業システムの改善などの検討は必要である.

（3）マーキング・ラベル貼付作業

この種の作業は, 製品や半製品に直接印字したり, 所 定のラベルを定められた位置, 方向に貼る作業, 並びに 塗装作業である. 特に, 塗装に関して塗装ムラ識別のた め, 同色系統でも色識別できるセンサの開発が課題とし てめげられる。

(4) パイリング作業

この種の作業は, 製品の端片, 板状の製品などを所定 の場所に積み重ねて置く作業, あるいはラインの流れに のつてくるものから対象となるものだけを拔き取る作業 である. 技術課題としては可搬重量の大きいものを，ラ インの流れにマッチングした速い動きで処置する必要が あるため, 剛性があって, 動作の高速化を可能にする構 造の研究があげられる.

(5) 築灯作業

製鉄所に関わる耐火構造設備のすべてを対象にして, 耐火物の壊し, れんが積み, モルタル吹き付けなどの作 業であり, 高温・粉塵の環境下で重量物運搬も加わるこ とで労働条件の改善の面からロボット化が早くから検討 されてきた作業である．本作業に関する技術課題は，高 
温環境下でのプロフィール計測，れんがとれんがのすき まの目地入れ，モルタル表面の平滑化仕上げ，および異 形物の把持である.

(6) 疵手入れ作業

製品あるいは半製品の企面の柴を検出して，グライン ダあるいは溶削にて除去する作業である，壮此の検出につ いては視覚センサを利用したかなり高速のものも実用化 されているが，これからは多種多様の疵の程度（深さ, 方向）を認識して，それに応じて動作するロボットの開 発が課題である.

（7）開孔・閉塞作業

この作業は, 孔部の詰め物の除去や孔部に詰め物を装 入する作業であり, 組み立て・装着作業と類似作業であ るが精度的にはラフであり開発すべき技術課題は少な い.

（8） バリ取り作業

本作業は角形, 丸形したものの端部の面取り，切断面 のカエリの除去をグラインダを使つて行ら作業である. 対象物の寸法精度，位置確認用センサの問題はあるが， 作業能率をあまり問題にしなければ灰現性は高い。これ からの技術課題は，形状や位置あるいは押付力を検知す るセンサの精度向上と動作の高速化があげられる.

(9) サンプリング作業

本作業は, 製品のテストピースの採取, 溶製時の成分 分析のための溶鋼採取あるいは鉣石採取などである. こ の種の作業に関する技術課題としては，たとえばテスト ピース用の試料部分を把持し溶断するような両手の協調 作業や動いているものに追従してつかみ取り出す作業が できる機構の研究があげられる。

(10) 溶接・溶断作業

製鉄所における溶接溶断作業は，機械組み立てのケー スのようにすべてが精度よく作られることが少ないため 問題が介在する.すなわち, 対象物の精度が出ていない ため, 高精度の形状識別センサの開発が望まれる.

(11) 清掃・整理作業

この種の作業は, 配管, ダクトなどの内側あるいは外 側の清掃, 並びに㴖などの不純物の除去, 製品の形状を
そろえ並べ積み上げなどである.この種の作 業の特 徵 は，漠然とした形状のものを対象にすることが多い上 に，要・不要を判別することであり，清掃すべきものと 本体との判断ができる高精度の識別センサの開発が望ま れる.

\section{6. 結 び}

ロボット研究小委員会活動のまとめをすると以下のご とくである。

（1）ロボットの定義あるいは解釈について，種々論 じられているが，JIS の定義に基づいて製鉄所のロボッ ト化の実態を探つてみると，マニアルマニプレータ方式 が主体で知能化はこれからである.

（2）今回の調査から製鉄所の各工程の中でもメイン ラインと言われる工程は，専用機あるいは自動化が積極 的に取り入れられてきたこともあつてロボット化のニー ズは少なく, 精整工程あるいはオフラインとなる附帯作 業にロボット化の関心が向いている.

（3）ロボット化ニーズの分析結果からすると, 鉄鋼 のイメージとしてある「重量物」をハンドリングした り，「高速処理」するケースが少なかつたこともあつて， 技術的見地からみると実現性の高い案件がかなりある.

（4）製鉄所に抢けるロボット化の拡大のための技術 課題は, センサの開発, 両手作業の場合の協調動作機構 などの研究があげられる。

（5）ロボット化ニーズは，人間が行つている作業の ロボット置換を前提として抽出したもので, ロボットの 導入を前提とした生産システムの改善なども検討すれば 製鉄所のロボットの適用率は高まつていくことが期待で きる。

なお，本研究小委員会では，各社各事業所でレイアウ ト, 情報の授受方法, 設備構造, 環境などロボット化の 条件が異なるため期待に応えられる具体案の提示までに は至らなかつた. しかしこれを一つの契機にして各社の 実情に適したロボット化ニーズを具体化して効果を出し ていただければ幸いである。 